\title{
Are Accounting Information Systems Programs Evolving to Meet the Needs of the Accounting Profession? An Analysis of Accounting Information Systems Programs in 2005 and 2019
}

\author{
Joseph B. O'Donnell \\ Canisius College
}

The paper investigates the number and content of U.S. Accounting Information Systems (AIS) programs in 2005 and 2019 to identify whether AIS programs are meeting the expanding need for accountants with IT knowledge. A dramatic decrease in graduate AIS programs and a slight decrease in undergraduate programs occurred from 2005 to 2019. Overall, graduate AIS programs meet the most recent IFAC and AICPA guidance on IT competencies better than undergraduate AIS programs. Offering AIS courses in data analytics programs and greater integration of data analytics in AIS programs raise opportunities for universities to provide its accounting graduates with in-demand skills.

Keywords: Accounting Information Systems Education, AIS Education, Accounting Education, Data Analytics Education, Accounting Analytics Education, AICPA, IFAC, Accounting Competencies

\section{INTRODUCTION}

Global competition and ever-changing technology require accountants to possess robust information technology (IT) skills. Business and accounting professional associations provide guidance on their professions' required skills and knowledge to meet employer and/or customer needs. The American Institute of Public Accountants (AICPA) and International Federation of Accountants (IFAC) issue core competencies for accountants that include IT competencies (American Institute of Certified Public Accountants [AICPA], 2018; International Federation of Accountants [IFAC], 2017). In addressing the need for accounting graduates possessing IT skills, colleges and universities include IT courses in accounting programs. Some schools provide specialized IT and IT assurance skills through Accounting Information Systems (AIS) programs. AIS programs vary in size and content, as there is no generally recognized curriculum standard across colleges and universities.

This paper compares the state of U.S. undergraduate and graduate AIS programs from 2005 and 2019. The comparison provides insights on trends in the number of programs and in changing emphasis of programs over 14 years. This study will evaluate the 2019 AIS programs in relation to IFAC and AICPA IT core competencies. 


\section{BACKGROUND ON AIS PROGRAMS}

AIS programs bridge the gap between accounting and technology. In the early 1990s, the Accounting Education Change Commission called for college and university accounting programs to include information systems content in accounting programs (Accounting Education Change Commission, 1991). In response to this edict, many schools offered a one-semester course in AIS while fewer schools also offered further programs of study in AIS. These AIS programs of study included majors, concentrations, tracks, and options in AIS (Bryant, Weishar \& Fordham, 1999). As of 1998, there were 35 graduate AIS programs and 8 undergraduate AIS programs in Association for the Advancement of Collegiate Schools of Business International (AACSB) accredited schools (Bryant, et al., 1999). By 2005, the AACSB undergraduate AIS programs more than quadrupled to 32 programs while conversely the graduate AIS programs decreased $20 \%$ to 28 programs. This study investigates whether these trends continued from 2005 to 2019.

\section{Guidance on Accounting IT Skills}

Accrediting business education associations, such as AACSB, and professional accounting organizations, such as IFAC and AICPA, emphasize the importance of accountants' IT skills. AACSB is a global organization that "connects educators, students, and business to achieve a common goal: to create the next generation of great leaders" (Association for the Advancement of Collegiate Schools of Business International [AACSB], n.d.). AACSB (2018) requires that accounting degree programs integrate current and emerging accounting and business information technologies including information systems and business processes, data analytics, and developing information technology agility.

IFAC promotes the worldwide development and enhancement of the accounting profession by providing global standards. IFAC's International Education Standards for Professional Accountants (IFAC 2003B; IFAC, 2015; IFAC, 2017) includes guidance for the development of an accountant's information technology skills. In addition, IFAC published International Education Guideline 11 (IEG 11): Information Technology for Professional Accountants (IFAC, 2003A) to assist in implementing these standards. The 2003 and 2015 IFAC standards recommend IT skills for an accountant in the following areas: general knowledge of information technology, IT control knowledge, IT control competencies (evaluation of control and risk assessment competencies), and IT user competencies (ability to apply appropriate IT systems and tools to business and accounting problems) (IFAC, 2003A; IFAC 2003B; IFAC, 2015). In addition, IFAC recommended one, or a mixture of, the specialized competencies of the roles of manager, evaluator, and/or designer of information systems for the accounting professional (IFAC, 2003A; IFAC 2003B; IFAC, 2015). The evaluator role competencies include necessary skills for internal and external auditors in providing assurance of system processes and controls (IFAC, 2003A; IFAC 2003B; IFAC, 2015). The manager role competencies include the skills and knowledge for professional accountants managing information systems to meet organization goals. Examples of competencies are the ability to assess effectiveness and efficiency of information systems, and the ability to judge whether an information system meets the needs of users (IFAC, 2015). Designer role competencies address the necessary skills of accountants in designing information systems. These competencies involve designer activities such as identifying user needs, assessing costs and benefits of systems solutions, effectively selecting systems solutions, and adeptly implementing and integrating new systems with business processes (IFAC, 2015).

More recently, IFAC's IES 2 dramatically changed the competencies by emphasizing data analysis, decision-making and business analytics and dropping discussion of the manager and designer role competencies (IFAC, 2017). The current IES 2 drops evaluator role terminology but includes discussion of evaluator related competencies for analyzing the adequacy of IT internal controls (IFAC, 2017). The current IES 2's IT related competencies include the following:

- Analyze the adequacy of general information technology controls and relevant application controls, 
- Explain how information technology contributes to data analysis and decision making, and

- Use information technology to support decision making through business analytics (IFAC, 2017, p. 36).

In the United States, the AICPA provides professional accounting core competencies that includes IT and other competencies. In general, the current AICPA's IT related competencies are similar to IFAC's. The AICPA recommends that professional accountants possess competencies that

- identify the appropriate businesses processes and system(s), related frameworks and controls to assist in the design and use of systems for efficient and effective operations, and

- identify and utilize relevant technology and tools to analyze data, efficiently and effectively perform assigned tasks as well as support other competencies. (AICPA, 2018, p. 2).

Similar to IFAC, AICPA competencies emphasize knowledge of system controls and use of IT to analyze data. In contrast to IFAC, AICPA includes professional accountants' role in systems development in relation to business processes, systems and controls.

IFAC recommends that accountants gain these IT competencies through a combination of educational and professional work experience (IFAC, 2003A; IFAC 2003B, IFAC, 2015; IFAC, 2017). Accounting graduates who take courses that address the foundational components of these IT competencies are better prepared for their accounting careers.

Delivery of the IT accounting competency material occurs through different courses and academic programs. First, introductory information systems courses, which are often part of a school's business core, typically cover general knowledge of IT and many IT user competencies. Second, an introduction to an accounting information systems course addresses IT control competencies and IT control knowledge and may cover additional IT user skills. Third, some universities and colleges deliver these skills through an AIS program. AIS programs that include specialized courses in IT and IT Audit could cover some mixture of the evaluator, manager, designer role competencies as well as business analytics. IFAC's guidelines offer a framework of knowledge that can be applied both to accounting programs and AIS programs. For example, AIS programs could be analyzed based on their relative emphasis on IT evaluator, manager, designer roles and data analytics competencies.

\section{AIS Curriculum}

The lack of generally accepted standards for programs creates difficulties for AIS educators, prospective AIS students, and employers hiring AIS graduates. AIS educators must decide what courses and topics to offer in the program. Bryant et al. (1999) gained an understanding of program content by analyzing course offerings in AIS programs. Their research identified courses included in AIS programs. They found that undergrad AIS programs had similar curriculum that included accounting courses along with programming, database, systems analysis and design, and telecommunications (Bryant et al., 1999). Conversely, graduate programs contained accounting courses but did not reflect similarity in IT courses across the schools in the study (Bryant, et al., 1999). Dillon and Kruck (2004) analyzed school demographics, curriculum, and topical coverage of undergraduate AIS programs with integrated accounting and information systems curriculum. This study evaluated integrated programs but did not address the less integrated AIS programs that were included in the Bryant, et al. (1999) study. Dillon and Kruck (2004) found that the undergraduate AIS programs mostly contained courses that were a combination of traditional accounting and information systems programs. These programs also included a few hybrid courses such as accounting information systems and information systems control and auditing (Dillon \& Kruck, 2004).

Dillon and Kruck (2008) found that employers of AIS graduates placed high importance on skills in the areas of enterprise resource planning (ERP), network issues, database design, and properly designed systems. In contrast, these employers placed low importance on skills in the areas of computer programming, process modeling with data flow diagrams and use of SQL to access data in databases (Dillon \& Kruck 2008). More recently, Pan and Seow (2016) recommended an AIS curriculum composed 
of four IT related courses (1) Business Process Analysis and Accounting, (2) IT Forensic, (3) Enterprise Systems, and (4) Business Analytics for Accountants.

This research paper fills a gap in the literature by extending these previous studies with an update on the status of AIS programs in terms of number of programs, mean credit hours and content. This research investigates whether the content has remained relatively unchanged since 2005 or has evolved to contain courses that are more reflective of recent guidance from IFAC and AICPA. This paper compares AIS program offerings in 2005 with those of 2019 to identify trends in AIS programs and to analyze whether schools are adequately addressing the necessary skills for graduating accountants. In addition, the paper investigates whether the number of schools offering AIS programs is expanding to meet the growing need of accountants with IT skills.

\section{METHODOLOGY}

The empirical research study involves the review of AIS programs in the United States in 2005 and 2019. The sample of schools for the study includes accounting departments of AACSB accredited business schools and is consistent with prior studies (Bryant, et al., 1998; O'Donnell, 2005). AACSB includes a significant number of schools, 429 schools in 2005 (AACSB, 2005) and 527 schools in 2019 (AACSB, 2019) and provides a basis for comparison between 2005 and 2019. AACSB business school websites were reviewed to determine whether the school offered an AIS program. Consistent with Bryant et al. (1998), AIS programs in this study included AIS majors, minors, concentrations, tracks, and options. For the schools offering AIS programs in 2005, their curriculum was obtained from school websites or from College Source Online (2005). Curricula for 2019 AIS programs were obtained from school websites. The study focused on AIS program IT related courses and not on a program's accounting courses consistent with Bryant, et al. (1999). This study reviewed course titles of required IT related AIS program courses as a basis for identifying the focus of AIS program content. Course titles communicate the overall focus of a course to students enrolling in the AIS major and employers hiring AIS graduates. The study did not categorize AIS elective courses as it is unclear which of the electives students are actually choosing. AIS programs provide coverage content beyond the basic IT general knowledge and IT foundational skills. This study categorizes courses as focusing on competencies of IT (1) evaluator, (2) manager and (3) designer roles (IFAC, 2003B; IFAC, 2015) as well as (4) data analytics competencies (IFAC, 2017). This analysis provides insight on the relative emphasis of programs in regards to the four competencies and the size of the AIS programs in terms of number of credit hours. Comparing the undergraduate and graduate programs in 2005 and 2019 sheds light on trends in the number of programs, changes to the programs, and whether these changes meet the current needs of the profession.

\section{RESULTS}

\section{Undergraduate AIS Programs 2005 and 2019}

As shown in Table 1, the total number of undergraduate AIS programs dropped from 32, in 2005, to 28, in 2019, representing a 13\% decrease over the 14-year period. From 2005 to 2019, 19 schools dropped AIS programs and 15 schools added AIS programs. As shown in Figure 1 and Table 1, the mean credit hours dropped for IT courses in the undergraduate AIS programs and for the individual categories, except for data analytics that increased slightly. The mean credit hours vary widely for the total AIS program and individual classifications, as shown in the relatively large standard deviations (in comparison to mean credit hours) and broad range of credit hours. The total AIS program mean credit hours dropped nearly two credit hours from 16.57 credit hours in 2005 to 14.79 in 2019 . The decrease is due to the programs added since 2005, offering fewer IT credit hours than the programs they replaced. Evaluator, manager, designer and IT electives all showed slight decreases in mean credit hours. Data analytics mean credit hours were zero in 2005 and minimal in 2019 with 0.21 mean credit hours. 
FIGURE 1

UNDERGRADUATE AIS PROGRAMS 2005 AND 2019

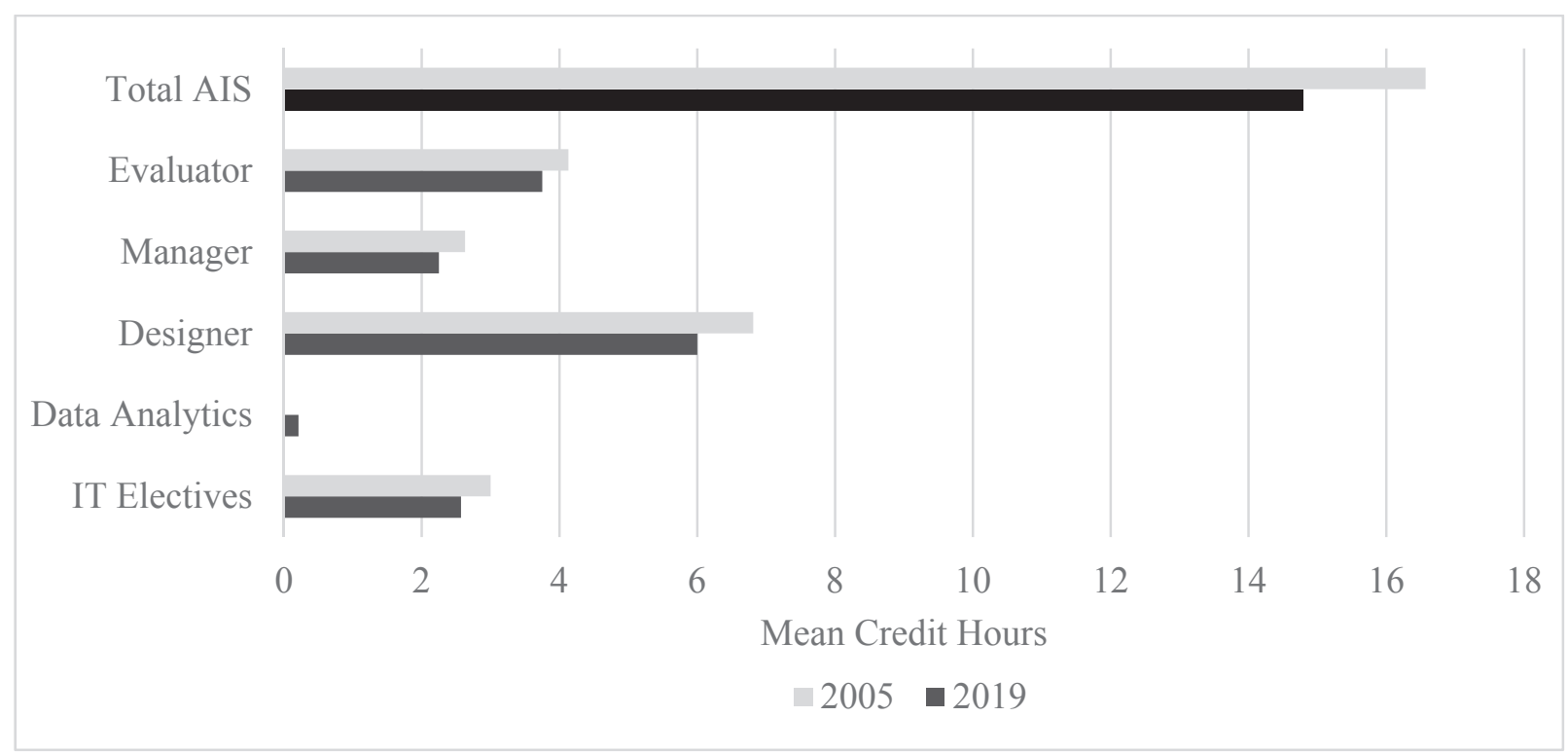

TABLE 1

UNDERGRADUATE AIS PROGRAMS 2005 AND 2019

\begin{tabular}{|c|c|c|c|c|c|c|c|c|}
\hline & \multicolumn{4}{|c|}{2005 Undergraduate Programs $(n=32)$} & \multicolumn{4}{|c|}{2019 Undergraduate Programs $(n=28)$} \\
\hline & \multirow{2}{*}{$\begin{array}{l}\text { Mean } \\
\text { Credit } \\
\text { Hours }\end{array}$} & \multirow{2}{*}{$\begin{array}{l}\text { STD } \\
\text { Dev }\end{array}$} & \multicolumn{2}{|c|}{ Credit Hour Range } & \multirow{2}{*}{$\begin{array}{l}\text { Mean } \\
\text { Credit } \\
\text { Hours }\end{array}$} & \multirow[b]{2}{*}{ STD Dev } & \multicolumn{2}{|c|}{ Credit Hour Range } \\
\hline & & & Low & High & & & Low & High \\
\hline Total AIS & 16.57 & 4.92 & 9.00 & 30.00 & 14.79 & 4.83 & 0.00 & 27.00 \\
\hline Evaluator & 4.13 & 2.24 & 0.00 & 9.00 & 3.75 & 2.4 & 0.00 & 9.00 \\
\hline Manager & 2.63 & 2.24 & 0.00 & 12.00 & 2.25 & 2.40 & 0.00 & 9.00 \\
\hline Designer & 6.81 & 4.27 & 0.00 & 21.00 & 6.00 & 4.97 & 0.00 & 18.00 \\
\hline $\begin{array}{l}\text { Data } \\
\text { Analytics }\end{array}$ & 0.00 & 0.00 & 0.00 & 0.00 & 0.21 & 0.79 & 0.00 & 3.00 \\
\hline $\begin{array}{l}\text { IT } \\
\text { Electives }\end{array}$ & 3.00 & 3.00 & 0.00 & 9.00 & 2.57 & 03.34 & 0.00 & 12.00 \\
\hline
\end{tabular}

Graduate AIS Programs 2005 and 2019

As shown in Table 2, a drastic reduction occurred in the number of graduate AIS programs from 28 in 2005 to 15 in 2019 representing a decrease of 13 or 46\% in the number of programs. From 2005 to 2019, 18 schools dropped their graduate AIS programs and five schools added graduate AIS programs. As shown in Figure 2 and Table 2, the mean credit hours increased from 2005 to 2019 for AIS Program IT courses and for evaluator, data analytics, and IT electives while manager and designer courses decreased. The mean credit hours vary widely for the total AIS program and individual classifications as shown in the relatively large standard deviations (in comparison to mean credit hours) and broad range of credit hours, see Table 2. As shown in Table 2, the number of mean credit hours for graduate AIS programs increased by 1.63 (15\%), from 13.24 in 2005 to 14.87 in 2019. The increase is due to larger credit hour programs replacing many of the smaller credit hour programs that dropped out. The biggest gains in credit hours are evaluator and IT electives with 1.68 and 2.29 of mean credit hour increases, respectively. These 
two also had the highest 2019 mean credit hour of 5.20 and 5.47 for evaluator and IT electives, respectively. Partially offsetting these increases are decreases in mean credit hours for designer of 1.94 and manager of 1.10. Data analytics courses were minimal in both 2005, 0.10 mean credit hours, and 2019, 0.80 mean credit hours, but 2019 did show a slight increase.

FIGURE 2

GRADUATE AIS PROGRAMS 2005 AND 2019

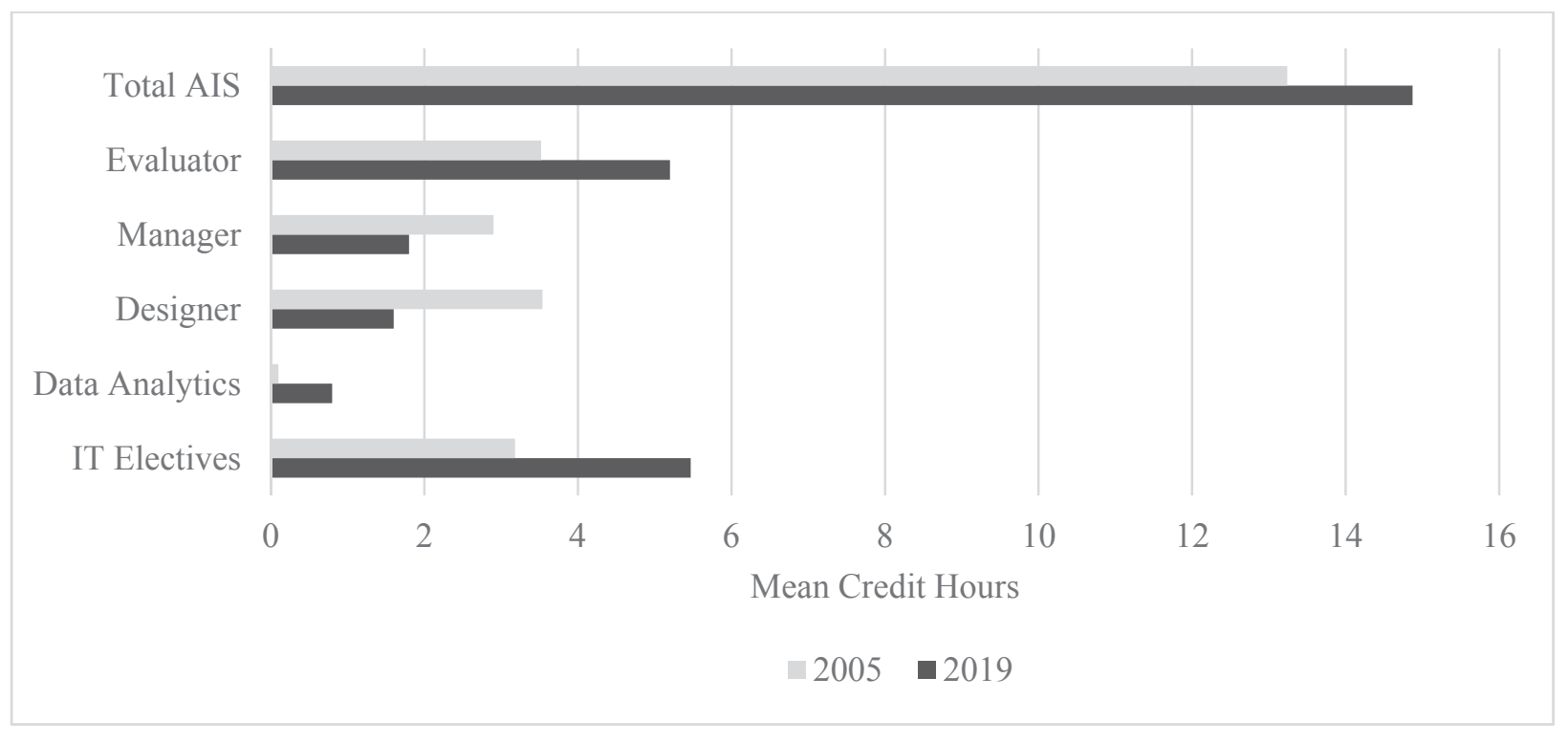

TABLE 2

GRADUATE AIS PROGRAMS 2005 AND 2019

\begin{tabular}{|c|c|c|c|c|c|c|c|c|}
\hline & \multicolumn{4}{|c|}{2005 Graduate Programs $(n=28)$} & \multicolumn{4}{|c|}{2019 Graduate Programs $(n=15)$} \\
\hline & \multirow{2}{*}{$\begin{array}{l}\text { Mean } \\
\text { Credit } \\
\text { Hours }\end{array}$} & \multirow{2}{*}{$\begin{array}{l}\text { STD } \\
\text { Dev }\end{array}$} & \multicolumn{2}{|c|}{ Credit Hour Range } & \multirow{2}{*}{$\begin{array}{l}\text { Mean } \\
\text { Credit } \\
\text { Hours }\end{array}$} & \multirow[b]{2}{*}{ STD Dev } & \multicolumn{2}{|c|}{ Credit Hour Range } \\
\hline & & & Low & High & & & Low & High \\
\hline Total AIS & 13.24 & 5.15 & 6.00 & 27.00 & 14.87 & 5.26 & 9.00 & 27.00 \\
\hline Evaluator & 3.52 & 3.03 & 0.00 & 12.00 & 5.20 & 5.25 & 0.00 & 15.00 \\
\hline Manager & 2.90 & 3.46 & 0.00 & 12.00 & 1.80 & 3.36 & 0.00 & 12.00 \\
\hline Designer & 3.54 & 3.50 & 0.00 & 12.00 & 1.60 & 2.50 & 0.00 & 6.00 \\
\hline $\begin{array}{l}\text { Data } \\
\text { Analytics }\end{array}$ & 0.10 & 0.57 & 0.00 & 3.00 & 0.80 & 1.78 & 0.00 & 6.00 \\
\hline $\begin{array}{l}\text { IT } \\
\text { Electives }\end{array}$ & 3.18 & 4.14 & 0.00 & 14.00 & 5.47 & 5.71 & 0.00 & 16.00 \\
\hline
\end{tabular}

\section{Comparison of Undergraduate and Graduate Programs}

Both undergraduate and graduate AIS programs decreased but undergraduate programs decreased slightly with four fewer programs while graduate programs drastically dropped by $46 \%$ or 13 programs. The increase in mean credit hours raised graduate programs (14.87 mean credit hours) in 2019 to essentially the same level as 2019 undergraduate programs (14.79 mean credit hours). In 2019, graduate program evaluator mean credit hours of 5.20 and IT electives of 5.47 are much higher than undergraduate evaluator hours of 3.75 and IT electives of 2.57. Meanwhile, the 2019 undergraduate AIS program designer 6.0 mean credit hours drastically exceeds the 1.60 mean credit hours of graduate programs. The 
2019 manager mean credit hours of 2.25 for undergraduate programs is slightly higher than 1.80 in graduate programs. In 2019, course offerings of data analytics are sparse for both graduate and undergraduate programs but slightly better for graduate AIS programs, with 0.80 mean credit hours compared to undergraduate AIS programs with 0.21 .

\section{Course Categories 2005 and 2019}

Comparing course categories from 2005 to 2019 provides insight on changes in course offerings over the 14-year period. Since 2005 in the evaluator competency area, the addition of computer forensics courses at the graduate and undergraduate level reflects the need for technology expertise coupled with fraud detection and prevention skills. Changes in the manager competency courses include the addition of legal environment of information systems and dropping of Ebusiness/ecommerce. The addition of the legal course recognizes the importance of legal issues such as copyrights and privacy concerns in modern systems. As Ebusiness became more common in business and everyday life, the need for a specialized course in this topic diminished. In regards to system designer competency courses, topic categories have changed little with the only difference being the dropping of programming courses at the graduate level for the 2019 courses. Lastly, there are more 2019 course categories in business analytics and analytics. However, there are a limited number of schools including these courses in their AIS programs as reflected in the low number of mean credit hours at the undergraduate and graduate level in 2019.

TABLE 3

\section{AIS COURSE CATEGORIES}

\begin{tabular}{|c|c|c|c|c|}
\hline & \multicolumn{2}{|c|}{$\begin{array}{l}\text { Undergraduate } \\
\text { Programs }\end{array}$} & \multicolumn{2}{|c|}{$\begin{array}{l}\text { Graduate } \\
\text { Programs }\end{array}$} \\
\hline & 2005 & 2019 & 2005 & 2019 \\
\hline \multicolumn{5}{|l|}{ Evaluator } \\
\hline IT/IS Auditing & $\mathrm{X}$ & $\mathrm{X}$ & $\mathrm{X}$ & $\mathrm{X}$ \\
\hline AIS & $\mathrm{X}$ & $\mathrm{X}$ & $\mathrm{X}$ & $\mathrm{X}$ \\
\hline Advanced AIS & $\mathrm{X}$ & $\mathrm{X}$ & $\mathrm{X}$ & $\mathrm{X}$ \\
\hline IT Security, Control, and Privacy & $\mathrm{X}$ & $\mathrm{X}$ & $\mathrm{X}$ & $\mathrm{X}$ \\
\hline Computer Forensics/Cyber Forensics & & $\mathrm{X}$ & & $\mathrm{X}$ \\
\hline \multicolumn{5}{|l|}{ Manager } \\
\hline Enterprise Systems & $\mathrm{X}$ & $\mathrm{X}$ & $\mathrm{X}$ & $\mathrm{X}$ \\
\hline Ebusiness/ecommerce & $\mathrm{X}$ & & $\mathrm{X}$ & \\
\hline Information Systems Management & $\mathrm{X}$ & $\mathrm{X}$ & $\mathrm{X}$ & $\mathrm{X}$ \\
\hline Project Management & & $\mathrm{X}$ & & $\mathrm{X}$ \\
\hline Legal Environment of Information Systems & & & & $\mathrm{X}$ \\
\hline \multicolumn{5}{|l|}{ Design } \\
\hline $\begin{array}{l}\text { Systems Analysis and Design, Structured Analysis, Systems } \\
\text { Development/implementation, Software Development }\end{array}$ & $\mathrm{X}$ & $\mathrm{X}$ & $\mathrm{X}$ & $\mathrm{X}$ \\
\hline Programming & $\mathrm{X}$ & $\mathrm{X}$ & $\mathrm{X}$ & \\
\hline Telecommunications, Networking and Data Communications & $\mathrm{X}$ & $\mathrm{X}$ & $\mathrm{X}$ & $\mathrm{X}$ \\
\hline Database & $\mathrm{X}$ & $\mathrm{X}$ & $\mathrm{X}$ & $\mathrm{X}$ \\
\hline \multicolumn{5}{|l|}{ Data Analytics } \\
\hline Data Mining & & & $\mathrm{X}$ & \\
\hline Business and Accounting Analytics & & $\mathrm{X}$ & & \\
\hline Advanced Accounting Analytics & & & & $\mathrm{X}$ \\
\hline Analytics and Emerging Technologies & & & & $\mathrm{X}$ \\
\hline
\end{tabular}




\section{DISCUSSION}

With the ever-expanding role of technology in daily working lives, a corresponding growth in the number of U.S. AIS programs could be expected. Instead, the number of graduate U.S. AIS programs in 2019 dropped by $46 \%$ since 2005 and U.S. AIS undergraduate programs dropped slightly during that period. Clearly, AIS programs are not meeting the expanding employer demand for accountants that possess technology skills. As evidence of the importance of technology skills, CPA firms have substantially increased the percentage of non-accounting new hires to $31 \%$ of all new hires in 2018 while the number of new hire accountants decreased (AICPA, 2019). Graduating accountants with strong technical skills could possibly reverse this trend of non-accountant hiring. Despite the strong demand for accountants possessing IT skills, the number of AIS programs is decreasing. Possible reasons for declining numbers of AIS programs span staffing and resource constraints for schools offering AIS programs to competing accounting student opportunities that dampen the enrollment in AIS programs.

Universities and colleges face staffing and available resource challenges in delivering AIS program courses. First, there is a limited supply of faculty with the specialized skills to teach AIS program courses (Apostolou, Dorminey, Hassell, \& Rebele, 2014; Dillon \& Kruck, 2008; Fordham, Bryant \& Benke, 1997). A dearth of top rated AIS research journals leads to fewer Ph.D. candidates pursuing AIS faculty careers and few universities offering Ph.D. programs in AIS (Krahel \& Vasarhelyi, 2014). In addition, a key AIS faculty member retiring or leaving for another school could lead a university or college to discontinue an AIS program. Second, Apostolou, et al. (2014) identified the lack of growth in AIS programs due to lack of resources, such as funding for additional courses and limited class size while using computer labs.

On the student demand side, accounting students often weigh CPA requirements and other accounting specializations in their decision to enroll in AIS programs. First, passing the CPA exam is a priority for most accounting students and the exam's limited AIS content limits student demand for additional AIS content (Krahel \& Vasarhelyi, 2014). Second, accounting departments offer concentrations, tracks or entire programs in specialized accounting areas such as taxation and forensic accounting. These attractive specializations may lead to fewer AIS majors. The availability of these specialties greatly benefit accounting students. However, it is unfortunate that students in these specialized areas may not have the room in their schedules to enroll in AIS programs to develop AIS skills that are beneficial to tax and forensic accounting professionals. Third, dramatic growth in the demand for data analytics offers another specialty option for accountants. This rapid expansion of data analytics across many industries has led colleges and universities to launch data analytics programs (Tate, 2017). In summary, AIS programs provide valuable skills for accounting students but compete with other skill providing programs and students' focus on CPA exam content.

IFAC competency guidance has changed significantly from 2005 to 2019. In 2005, IFAC professional guidance recommended competencies for evaluator, designer and manager roles. By 2019, professional guidance from IFAC has changed to emphasizing evaluation of general and application controls (evaluator competencies) along with decision-making and business analytics competencies (IFAC, 2017). The most current AICPA guidance recommended IT skills that are similar to IFAC in the focus on information system controls and data analytics (AICPA, 2018). In addition, AICPA competencies include assisting in system design as it relates to controls, frameworks and processes (AICPA, 2018). AIS programs should be flexible enough to allow changes in curriculum that address new technologies (Fordham, et al., 1997) and the changing needs of the accounting profession. Thus, one might expect that a strong emphasis on evaluator skills, increased emphasis on data analytics competencies and less, possibly little or no, emphasis on designer and manager competencies in AIS programs.

As mentioned previously, the mean number of undergraduate AIS program credit hours declined from 2005 to 2019 for evaluator, designer and manager competencies. With the continued importance of evaluator competencies, it is surprising that evaluator credit hours would diminish. Designer competencies has the largest number of mean credit hours, 6.0, yet it is absent from the most recent IFAC 
guidance (IFAC, 2017). AICPA guidance is silent regarding accountants' competencies related to performing technical system development functions, such as systems analysis and design and programming. Data analytics coverage is minimal with mean credit hours at less than one average credit hour in the undergraduate programs. Possible options for increasing coverage in data analytics and evaluator competencies might be reducing credit hours in system designer and manager courses and/or reducing IT electives. Another option is revising designer courses to concentrate on data analytics skills such as computer programming courses focused on languages used for data analytics.

The 2019 graduate AIS programs reflect the importance of evaluator competencies with 5.5 mean credit hours, the largest number of credit hours among the four competencies. Deemphasizing manager, 2.5 mean credit hours, and designer, 2.0 mean credit hours, is consistent with IFAC and AICPA guidance. Mean credit hours of AIS graduate data analytics competencies courses is less than one credit hour. This meager coverage is not consistent with AICPA and IFAC guidance. One possible solution is adding a required course in data analytics while reducing IT electives that account for 5.58 mean credit hours in 2019.

Both graduate and undergraduate programs face impediments to curriculum change. First, the shortage of faculty with hybrid accounting and technology skills not only limits the number of AIS programs but also may limit the courses offered within AIS programs. For instance, accounting faculty may desire to add evaluator courses to the AIS program but their schools may not have qualified faculty to deliver the courses. Second, curriculum change is an involved process when creating new courses. Curriculum change often involves approval from university or college curriculum committees and governing boards and, in some cases, approval of the state where the school resides. Undergraduate business programs typically include liberal arts and science courses in addition to general business courses and business major courses. The undergraduate program's inclusion of areas across the school may lead to a lengthier process for gaining approval of new curriculum. Conversely, graduate business programs are often contained within the business school that may result in a speedier path for approving new curriculum. Perhaps the quicker pace of curriculum approval has aided some graduate programs in changing to meet the most current IFAC and AICPA competencies standards. This is a possible reason that graduate AIS programs align more closely with IFAC and AICPA competencies standards than undergraduate AIS programs.

Data analytics programs, integrated with AIS evaluator courses, offer an ideal opportunity to meet the IT competency needs of the accounting profession. Data analytics programs are sprouting up at many schools across the country to keep up with the big data explosion in businesses (Tate, 2017). Colleges and universities offer graduate and undergraduate data analytics programs in business schools or in other parts of the institutions. College and university accounting departments that offer data analytics programs provide an outstanding opportunity for their students to blend knowledge of accounting with the data analytics technical skills. These analytics programs include stand-alone undergraduate or graduate programs or concentrations, tracks or options in undergraduate or Master of Science accounting programs. However, data analytics programs do not inherently include business process and systems control competencies recommended by the AICPA (2018) and IFAC (2017). Colleges and universities that include courses related to evaluating business processes and systems control graduate accounting students with a skill set that is in dire need in the workplace.

In addition to capitalizing on the swelling demand for accountants with data analytic skills, the integrated data analytics and AIS program offers solutions to resource constraint issues that have limited the supply of AIS programs (Apostolou, et al., 2014). These integrated programs lessen the strain on the limited faculty with hybrid accounting and IT skills. Faculty in the areas of statistics, business intelligence and computer programming would teach data analytic courses, while the hybrid accounting IT skilled faculty would teach crucial AIS courses. Additionally, the integrated data analytics AIS program involves fewer courses, than a traditional AIS program, that require instructional computer labs that limit class size (Apostolou, et al., 2014).

Data analytics programs offer a potential solution to IT needs for accounting professionals. Some colleges and universities house data analytics programs in the accounting department and/or offer data 
analytics as a concentration in an undergraduate or graduate accounting program. These programs increase the opportunities for accounting graduates to develop in demand data analytics core competencies. Therefore, colleges and universities should integrate IT competencies as part of, or in addition to, their data analytics program.

This research study analyzes AIS programs in meeting professional accounting standards. A natural extension of the study is analyzing whether AIS programs are meeting employers' needs for particular accountants' IT skills. Ultimately, AIS programs should be graduating students that possess the skills that businesses require. Surveying employers offers opportunities to gain a greater understanding of general and specific IT competencies requirements. The IFAC and AICPA guidance reflects input from the business community and communicates best practices to accountants at a broad level. Extending this research by surveying employers would shed light on the perceived value of specific skills. This research would provide insight to educators and researchers on the specific content of an AIS program that complements the overall content areas identified in this research study.

\section{CONCLUSION}

Overall AIS programs are not meeting the expanding need for accountants with IT skills as the number of AIS programs diminished from 2005 to 2019. In general, both undergraduate and graduate AIS programs should increase coverage of data analytics competencies to be consistent with professional accounting associations' guidance. Overall, graduate AIS programs are emphasizing important evaluator of controls and information systems competencies, while on average AIS undergraduate programs should increase emphasis on these skills to be on par with the average credit hours in the graduate AIS programs. Launching new data analytics programs that include coverage of evaluating business processes and information systems controls offers a promising approach to addressing needed accounting IT competencies.

\section{REFERENCES}

American Institute of Certified Public Accountants (AICPA). (2018). The AICPA Pre-certification Core Competency Framework Core Competency. Retrieved from

https://www.aicpa.org/content/dam/aicpa/interestareas/accountingeducation/resources/downloada bledocuments/aicpa-pre-certification-core-compentency-framework.pdf

American Institute of Certified Public Accountants (AICPA). (2019). 2019 Trends in the Supply of Accounting Graduates and the Demand for Public Accounting Recruits. Retrieved from https:/www.aicpa.org/content/dam/aicpa/interestareas/accountingeducation/newsandpublications/ downloadabledocuments/2019-trends-report.pdf

Association for the Advancement of Collegiate Schools of Business (AACSB) (2005). List of accredited institutions, AACSB, St. Louis, Mo.

Association for the Advancement of Collegiate Schools of Business (AACSB) (2018). 2018 Eligibility Procedures and Accreditation Standards for Accounting Accreditation. Retrieved from https://www.aacsb.edu/-/media/aacsb/docs/accreditation/accounting/standards-and-tables/2018accountingstandards.ashx?la=en\&hash=8DCDA6CE3B0CEF6AB82D39CBF53995DA96111196

Association for the Advancement of Collegiate Schools of Business (AACSB) (2019). List of Accredited Institutions. Retrieved August 1, 2019 from https://www.aacsb.edu/membership/listings/alleducational-members

Association for the Advancement of Collegiate Schools of Business (AACSB) (n.d.). Who we are. Retrieved August 3, 2019, from https://www.aacsb.edu/about

Accounting Education Change Commission. (1991). Objectives of education for accountants. The Commission. 
Apostolou, B., Dorminey, J. W., Hassell, J. M., \& Rebele, J. E. (2014). A summary and analysis of education research in accounting information systems (AIS). Journal of Accounting Education, 32(2), 99-112.

Bryant, S. M., Weishar, J. K., \& Fordham, D. R. (1999). A survey of accounting information systems programs in U.S. colleges and universities. Review of Business Information Systems (RBIS), 3(2), 1-12. https://doi.org/10.19030/rbis.v3i2.5423

College Source Online. (2005). Database of digital college catalogs. https://cso.collegesource.com/

Dillon, T. W., \& Kruck, S. E. (2008). Identifying employer needs from accounting information systems programs. Journal of Information Systems Education, 19(4), 403-410.

Fordham, D. R., Bryant, S. M., \& Benke, R. L. Jr. (1997). The evolution of an accounting information systems concentration: Concepts and an example. Review of Business Information Systems (RBIS), 1(3), 1-10. https://doi.org/10.19030/rbis.v1i3.5498

Krahel, J. P., \& Vasarhelyi, M. A. (2014). AIS as a facilitator of accounting change: Technology, practice, and education. Journal of Information Systems, 28(2), 1-15.

International Federation of Accountants (IFAC). (2003A). International Education Guideline 11: Information Technology for Professional Accountants, New York, N.Y.

International Federation of Accountants (IFAC). (2003B). International Education Standards for Professional Accountants, New York, N.Y.

International Federation of Accountants (IFAC). (2015). Handbook of international education pronouncements, 2015 edition. Retrieved from https://www.ifac.org/publications-resources/2015handbook-international-education-pronouncements

International Federation of Accountants (IFAC). (2017). Handbook of international education pronouncements, 2017 edition. Retrieved from https://www.ifac.org/publications-resources/2017handbook-international-education-pronouncements

O'Donnell, J.B. (2005). What's in a Name? Categorizing U.S. undergraduate accounting information system programs, presented at the 2005 Accounting Information Systems Educators Conference, Breckenridge, Colorado.

Pan, G., \& Seow, P. S. (2016). Preparing accounting graduates for digital revolution: A critical review of information technology competencies and skills development. Journal of Education for Business, 91(3), 166-175

Tate, E. (2107, March 15). Data analytics programs taking off at colleges. Inside Higher Ed, Washington, D.C. Retrieved from https://www.insidehighered.com/print/digitallearning/article/2017/03/15/data-analytics-programs-taking-colleges 